University of Nebraska - Lincoln

DigitalCommons@University of Nebraska - Lincoln

\title{
Lixus cardui, a biological control agent for scotch thistle (Onopordum acanthium): Safe for Australia, but not the USA?
}

Joe Balciunas

USDA-ARS

Follow this and additional works at: https://digitalcommons.unl.edu/usdaarsfacpub

Part of the Agricultural Science Commons

Balciunas, Joe, "Lixus cardui, a biological control agent for scotch thistle (Onopordum acanthium): Safe for Australia, but not the USA?" (2007). Publications from USDA-ARS / UNL Faculty. 329.

https://digitalcommons.unl.edu/usdaarsfacpub/329

This Article is brought to you for free and open access by the U.S. Department of Agriculture: Agricultural Research Service, Lincoln, Nebraska at DigitalCommons@University of Nebraska - Lincoln. It has been accepted for inclusion in Publications from USDA-ARS / UNL Faculty by an authorized administrator of DigitalCommons@University of Nebraska - Lincoln. 


\title{
Lixus cardui, a biological control agent for scotch thistle (Onopordum acanthium): Safe for Australia, but not the USA?
}

\author{
Joe Balciunas * \\ USDA-ARS Exotic and Invasive Research Unit, Western Regional Research Center, 800 Buchanan St., Albany, CA 94710, USA
}

Received 16 November 2006; accepted 19 December 2006

Available online 28 December 2006

\begin{abstract}
Invasive exotic plants are often weeds in more than one country. After a biological control agent for a weed has been developed for use in one country, it is reasonable to consider using the same agent against the same weed in another country. 'Transfer Projects' can save considerable time and money, and they have been popular around the world. Lixus cardui Olivier (Coleoptera: Curculionidae), a weevil from Europe, was first used by Australian researchers to control Scotch thistle, Onopordum acanthium L. (Asteraceae). There are few close relatives of Scotch thistle in Australia, but that is not the case in North America, where scotch thistle is also an important weed. I initiated a project to test some of the agents released in Australia to see if they would be appropriate for release in the United States. Test plants, primarily Cirsium spp. thistles native to California, were exposed under both choice and no-choice conditions to two populations of $L$. cardui, one from Greece, the other from France. The latter may represent an undescribed species, and its test results are reported separately. Both strains of $L$. cardui weevils fed heavily and developed on some native North American thistles, at a level comparable to the target weed, Scotch thistle. Consequently, our laboratory colonies of $L$. cardui were terminated, and I will not seek its release in the United States. Even though, L. cardui has established well in Australia since its release in 1993, and dispersed widely there without causing problems, it is inappropriate to release it in the United States.
\end{abstract}

Published by Elsevier Inc.

Keywords: Host specificity; Lixus cardui; Non-target impacts; Onopordum acanthium; Potential host range; Risk assessment; Scotch thistle; Transfer project; Weed biological control

\section{Introduction}

Many exotic weeds have become so widespread and invasive, that they cause problems in more than one country, sometimes on several continents. If one country develops a classical biological control agent for one of these widespread weeds, it is logical that another country would consider using the same agent for the same weed in their country. The high costs of foreign exploration and testing could be reduced or avoided, and there is the possibility of controlling the weed sooner, rather than later. Thus, 'transfer projects' where biological control agents developed for use in one country are subsequently also

\footnotetext{
* Fax: +1 5105595982.

E-mail address: joe@pw.usda.gov
}

used elsewhere, are appealing. In fact, the numerical 'scoring' system for potential weed biological control agents developed by Harris (1973) and revised by Goeden (1983) assigned a high number of points (12) to agents that had proven "Successful in two or more regions of the world" (Goeden, 1983, p.293). On a global basis, transfer projects have become popular, especially in less developed countries. Perhaps the best example of this is the South American weevil Neochetina eichhorniae Warner, a biological control agent for waterhyacinth, Eichhornia crassipes (Martius) Solms-Laubach, which has been released in more than three dozen countries since 1971 (Julien and Griffiths, 1998; CAB International, 2004). An example for a terrestrial weed is Teleonemia scrupulosa Stål (Hemiptera: Tingidae), which has been released in over 30 countries to control Lantana camara L. (Julien and Griffiths, 1998; CAB International, 2004). 
Scotch thistle, Onopordum acanthium L., is another global weed, recorded from nearly 50 countries $(\mathrm{CAB}$ International, 2004), with many of these countries interested in finding effective biological control agents for it. Some of the agents approved for other thistle species, such as musk thistle, Carduus nutans L., will occasionally attack Scotch thistle as well, and there have been attempts to use some of these as biological control agents for the latter (Coombs and Turner, 1995). Australia was the first country to initiate a biological control effort specifically targeting Scotch thistle. This was a model weed biological control project, worthy of emulation. First the Australian researchers and their overseas cooperators surveyed the insect fauna on Onopordum spp. thistles in Europe and the Mediterranean region, then determined the niches, probable impact, and field host specificity of the most promising potential agents (Briese et al., 1994, 1995; Briese, 1996). Eventually, seven insects, all from Europe, were released in Australia (Briese et al., 2002a; Swirepik and Smyth, 2002).

Scotch thistle is also a major problem in North America. This large, spiny thistle frequently exceeds $2 \mathrm{~m}$ in height, and can grow as tall as $3.7 \mathrm{~m}$ [12 ft.] (Whitson et al., 1996). It replaces more desirable plant species utilized by livestock and wildlife, and dense stands can prevent access to water sources, and deter recreational activities (Young and Evans, 1969; Hooper et al., 1970). It is found in five Canadian provinces, although it is only a serious problem in Ontario (Moore and Frankton, 1974), and in 37 of the 48 contiguous states in the USA. (USDA-NRCS, 2006). While Scotch thistle, like bull thistle, Cirsium vulgare (Savi), infests pastures and wet meadows, it also readily invades much drier sites (Young and Evans, 1969). In the United States, Scotch thistle is most problematic in the arid portions of the Northwest, as well as California and Nevada. Since the late 1970's, there has been an exponential expansion in the number of counties in the Northwest that have been infested by this weed (Rice, 2006).

In 1996, several state agencies agreed to provide financial and in-kind assistance for a project I had proposedto begin testing some of the Scotch thistle agents that had been released in Australia to verify if they were safe to use in the USA. After consulting with Dr. David Briese, the scientist in charge of the Australian Scotch thistle project, I chose to begin our testing with Lixus cardui Olivier (Coleoptera: Curculionidae). The adults of this univoltine weevil feed on leaves and later, after Scotch thistle 'bolts', on the stems of Onopordum spp. thistles. The overwintering females oviposit within cavities they have chewed into the flowering stem, and the developing larvae burrow, feed, and pupate within the stem, emerging as adults a few months later (for more details about the biology of this weevil, see Volonik, 1994; Briese et al., 2004). This weevil, first released in Australia in 1993, established there readily, and has already shown promise that it would contribute to control of Scotch thistle (Briese et al., 2002b). It also appeared to be highly host specific, and restricted to feed- ing on species within the genus Onopordum (Zwölfer and Brandl, 1989; Briese et al., 1994, 2004).

Scotch thistle is a member of the thistle Tribe Cardueae of the family Asteraceae, and is placed in the subtribe Carduinae (Bremer, 1994). Australia has few natives in the thistle tribe (Bremer, 1994). Thus, the close relatives of Onopordum that were tested by the Australians were mostly crop plants and weeds. However, the North American thistle flora is much richer. Besides the weeds tested by the Australians, we also have numerous natives. The genus Cirsium has over 100 recognized taxa in the United States, the vast majority of which are native (USDA-NRCS, 2006). A large number of native Cirsium species have restricted geographic ranges, and some of these are federally or state listed as "Threatened" or "Endangered" [T \& E]. If there is evidence that, under field conditions, $L$. cardui might significantly damage one of these "T \& E" Cirsium species, there would be little hope of ever obtaining permission for its release in the United States. My strategy was, therefore, to test only members of the subtribe Carduinae, concentrating on native Cirsium spp., including a few listed "T \& E" species. To help gauge if our weevils were responding similarly to those tested by the Australians, some of the same weeds that the Australians tested were included in our host range studies.

\section{Materials and methods}

The host specificity tests were conducted in the USDAARS biological control of weeds quarantine facility in Albany, California, during the summers of 1996 and 1997. Ambient temperatures in the quarantine greenhouse containing the test cages ranged from 18 to $28^{\circ} \mathrm{C}$, and with long day lengths (13-14.8 h), no supplemental lighting was used. The females of $L$. cardui will usually only oviposit on flowering stems. All the test plants and the Scotch thistle controls used in our tests had matured to the point where they had 'bolted' and produced at least one 'bud' (technically, a specialized inflorescence known as a capitulum). The Scotch thistle used in our tests was provided by California Department Food and Agriculture's Biological Control Program, while all the remaining test plants were grown, from seeds, at our USDA-ARS greenhouse in Albany, California.

In May of 1996, I collected L. cardui adults at four different sites near the city of Thessaloniki, in northern Greece, and then, with appropriate permits, hand-carried them back to our quarantine facility in California. Out of the 264 weevils in this shipment, 163 were collected from O. acanthium, while the remainder was found on other species of Onopordum. For the 1997 tests, I collected another 235 weevils from Onopordum spp. at another site near Thessaloniki, and 230 more Lixus in a suburb of Montpelier, France, on $O$. acanthium and $O$. tauricum Danin. A second shipment of 117 French Lixus, collected by colleagues at USDA-ARS Montpellier research station, was received in 1997. Because of the possibility of the Lixus 
from France being a different species, they were tested separately from the $L$. cardui from Greece. However, to my knowledge, there have not yet been any published molecular or morphological studies comparing these two populations of Lixus weevils. When they were not being used in an experiment, the weevils were held at approximately $10^{\circ} \mathrm{C}$ in a refrigerator with a leaf of Scotch thistle. When setting up a test, my assistants and I tried to use 'new' weevils in each test, but towards the end of summer, many, especially males, had died, and we occasionally used some weevils that had been used in previous tests. Most of the specimens used in our tests are retained in our collection at Albany, California, and voucher specimens have been deposited at the USDA-ARS Systematic Entomology Laboratory, to be incorporated into the United States National Museum (USNM), in Washington DC.

Within the containment facility at the same site, we set up two types of host range tests: no-choice and choice. Both types of tests were conducted using wooden sleeve cages, each approximately 42 by 49 and $73 \mathrm{~cm}$ high, with a glass side. We began each no-choice test by placing a potted Scotch thistle plant into the center of the cage and then releasing 3-4 pairs of Lixus weevils on the soil below the plant. After 3 days, the Scotch thistle was replaced with a test plant species, and after an additional 6 days, the nochoice test was ended, and the living weevils were transferred to the (see Fig. 1) refrigerator. Any weevil that died during a test was replaced with another of the same sex. The amount of feeding on each plant was measured by overlaying a transparent $50 \times 50 \mathrm{~mm}$ grid over the damaged portions of the plants. After the test ended, the test plant and the Scotch thistle control were transferred to separate holding cages, where over the next two months, they were monitored for possible development of Lixus larvae. Occasionally, especially if feeding was heavy, the leaves would wither and dry up before the experiment ended (see Fig. 1), making accurate measurement of feeding damage impossible, but these plants were monitored for weevil development.

The choice tests were similar, except that each test began with both the test plant and the Scotch thistle control in the same cage, but not in contact with each other, and the weevils were released evenly below each plant. The duration of the choice tests was 3 days.

Approximately two months after the end of a choice or no-choice test, both the test plant and its Scotch thistle control were dissected, and the adults and developing immatures counted. We detected very few dead larvae, and if we had delayed our dissections, nearly all would have reached the adult stage. Therefore, only the total progeny for each plant species is reported.

We attempted to replicate each no-choice and choice test five times. Scotch thistle, along with most of the test plant species, is a biennial. Therefore, it took at least one year to get the plants used in our tests to the stage where they would be acceptable for oviposition by Lixus. By late July, most of the weevils had died. Often, we would have appro-

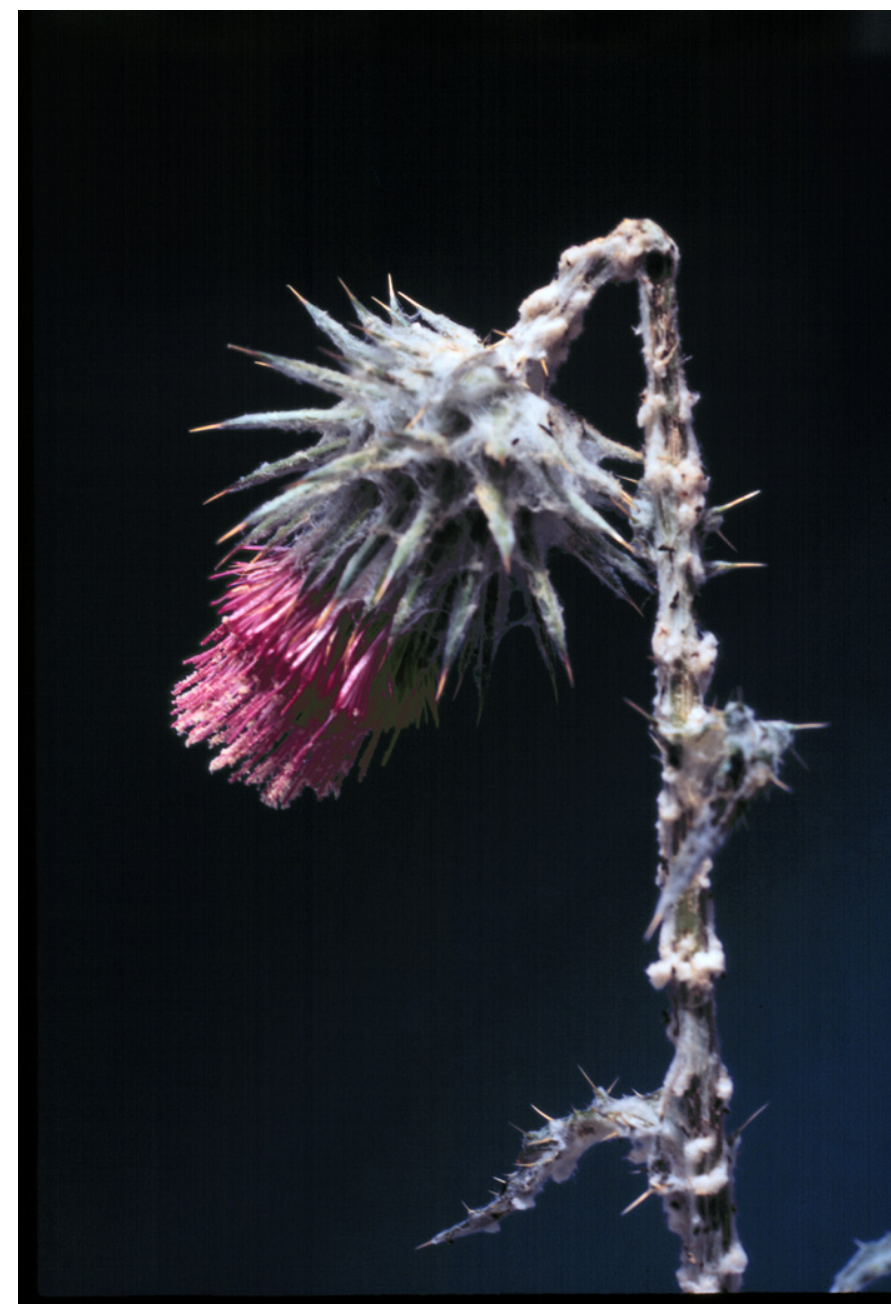

Fig. 1. Feeding damage to snowy thistle, Cirsium occidentale variety candidissimum, a native North American thistle, after six days of exposure to four pairs of Lixus cardui adults under no-choice conditions.

priate plants, but not enough weevils - or vice versa. Getting five replicates for each test plant species during two years was not always possible.

Before statistical analysis, the weevil count data were transformed by square root $(\mathrm{Y})$, or by square root $(\mathrm{Y}+0.5)$ for data with zero values (Sokal and Rohlf, 1981). The feeding and development data for each set of no-choice and choice trials were first analyzed separately using a one-way ANOVA procedure, and if significant differences were found, the data were further analyzed using Tukey's HSD All-Pairwise Comparisons Test to determine which species were significantly different from each other (Statistix, 2005).

\section{Results}

A list of all the plant species tested, and comments on their distribution and rarity, appear in Table 1. The scientific names of plants follow Hickman (1993) and PLANTS database (USDA-NRCS, 2006), while the common names 
Table 1

List of plants used in host range tests of Lixus cardui weevils. All plants are in the subtribe Carduinae, of the thistle tribe (Asteraceae: Cardueae)

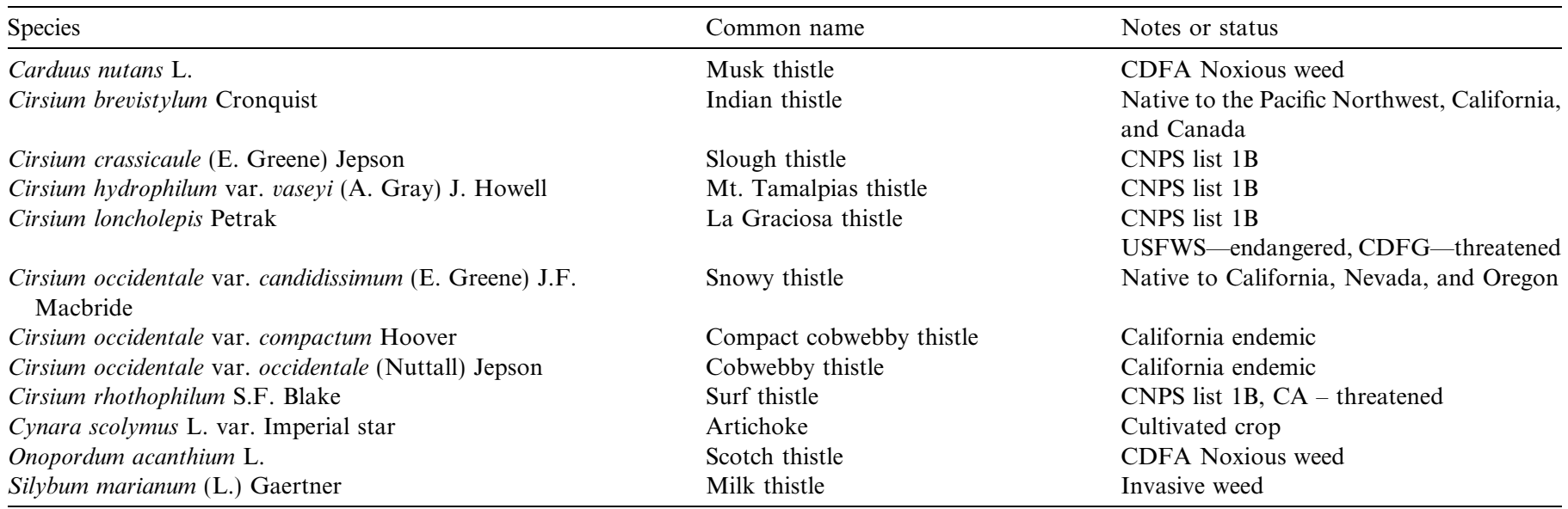

CNPS - California Native Plant Society list 1B - Rare or endangered in California and elsewhere (CNPS, 2003). USFWS-United States Fish and Wildlife Service. CDFG - California Department of Fish and Game. CDFA (California Department of Food and Agriculture) Noxious weed status from List of pest rating of noxious weed species and noxious weed seed (CDFA, 2006).

conform to Hickman (1993); WSSA (1989). The rarity and legal status of the various plant species follows CNPS (2001). When appropriate, we list the variety or subspecies of the plants we tested. These 'below species' designations are used by government regulatory bodies, and some, at one time, had species status (Munz, 1959).

\subsection{Host range tests with Greek weevils}

We were able to complete 26 no-choice tests using the L. cardui weevils collected in northern Greece (Fig. 2). In three tests, some leaves, heavily damaged by feeding, had withered to the extent that the feeding damage could not be measured. For Cirsium hydrophilum var. vaseyi, this left only one plant with a measurement of feeding damage, thereby preventing statistical comparison with feeding on other plant species. Under no-choice conditions, the L. cardui from Greece fed on all nine species of plants that we tested. The feeding was especially heavy on the native snowy thistle, Cirsium occidentale variety candissimum (see Fig. 1 for an example), averaging $143 \mathrm{~mm}^{2}$ per weevil per day. The mean amount of feeding on the seven thistle

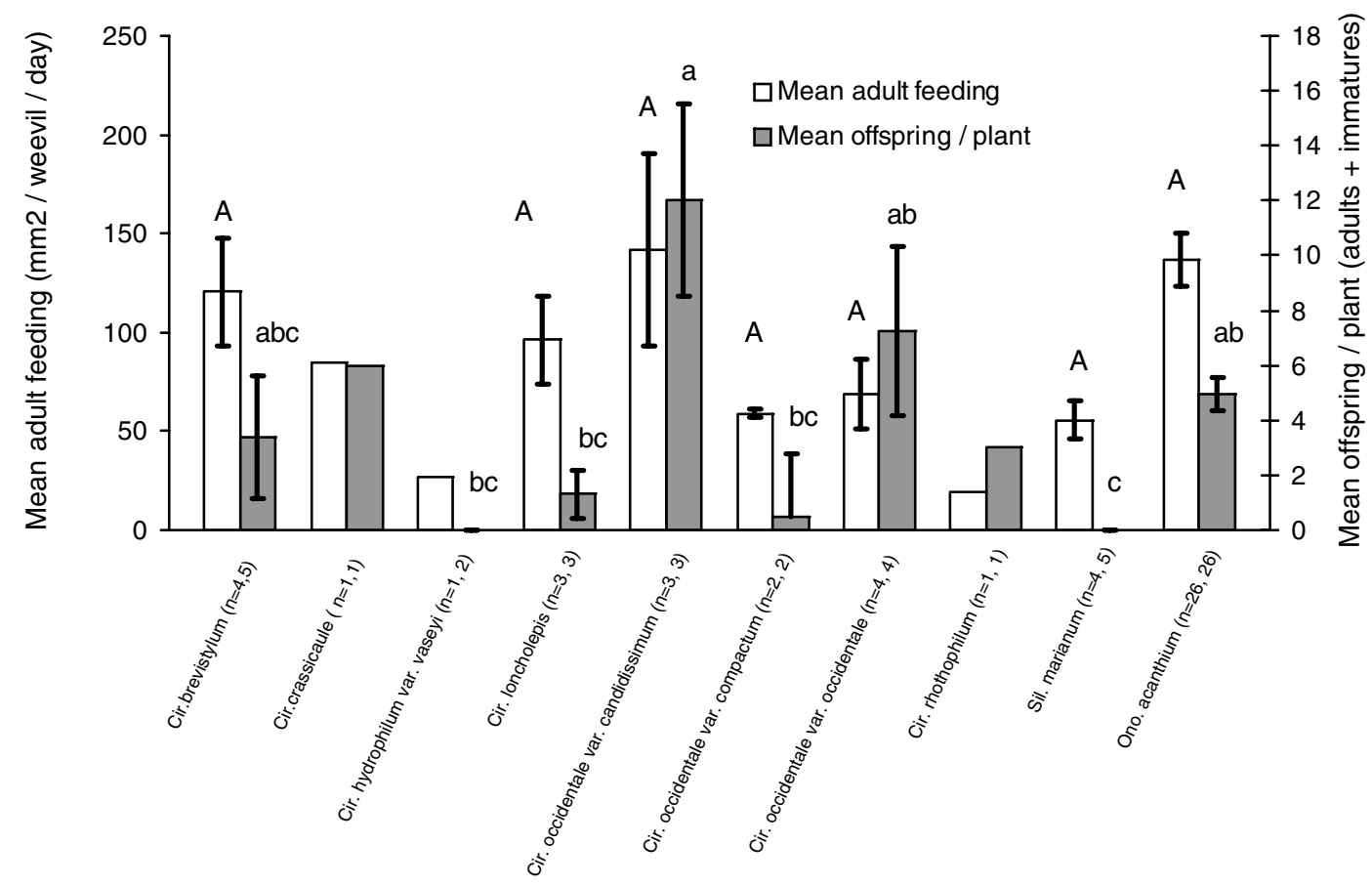

Fig. 2. Mean amount of adult feeding $\left(\mathrm{mm}^{2}\right)$ and mean number of larvae, pupae and adults subsequently developing on each test plant species exposed to Lixus cardui from northern Greece under no-choice conditions. The two $n$-values after each plant species name indicate the number of replicates with feeding scores and developmental data, respectively (see Section 2). The line above each bar indicates the SE. If the letters above the species bar are identical, then the means are not significantly different $(P \leqslant 0.05$, Tukey's HSD Test). 
species that had more than one replicate [the two with one replicate each could not be included in the statistical analyses] was not different statistically from the mean of $138 \mathrm{~mm}^{2}$ per weevil per day of feeding on Scotch thistle. The mean amount of feeding $\left(56 \mathrm{~mm}^{2}\right.$ per weevil per day) by Greek Lixus on milk thistle, Silybum marianum, was $41 \%$ of that on Scotch thistle, much greater than the $3 \%$ the Australian researchers reported during their no-choice tests of milk thistle (Briese et al., 2004) using Lixus from France.

Under no-choice conditions, the $L$. cardui weevils from Greece oviposited and were able to develop on all of the test plant species, except Cirsium hydrophilum var. vaseyi, a rare California thistle, and milk thistle (Fig. 2). The mean number of progeny that developed on each of the other five thistle species that had more than one replicate was not significantly different from the mean 5.0 progeny developing on the Scotch thistle controls (Fig. 2).

No-choice tests predict what might happen in a 'worstcase scenario', such as if large populations of $L$. cardui weevils were to remain at a site after they destroy the target weed, Scotch thistle. We also tested five of these same thistle species under, what is usually considered more realistic choice conditions (Cullen, 1990), where the weevils could 'choose' between Scotch thistle and one of its relatives. In two tests with Cirsium brevistylum, a native thistle, the weevils failed to oviposit on either it or the Scotch thistle control. We excluded from analyses the development data [but not the feeding scores] from these two tests because we could not be sure that the weevils used in those tests were capable of oviposition. Under choice conditions, the Greek Lixus still fed on all five test species, but the amount of feeding was always statistically significantly less than the mean of $118 \mathrm{~mm}^{2}$ per weevil per day observed on the Scotch thistle controls (Fig. 3). However, once again the feeding on snowy thistle was heavy (at least $30 \mathrm{~mm}^{2}$ per weevil per day), but we were only able to accurately measure the damage to one of the four plants we used, preventing statistical comparison of feeding damage with this species. We confirmed development on all three varieties of Cirsium occidentale, but for two varieties (var. candissimum and var. occidentale) this was statistically less than the mean of 4.8 progeny that developed on the Scotch thistle controls.

\subsection{Host range tests with French weevils}

I had planned to conduct further tests with this Lixus from Greece - in order to get the number of replicates up so that statistical comparisons would be more valid. However, it was already apparent that this weevil presented a threat to some of our native thistle species, and should not be released. Around this time, I learned from a weevil taxonomist that $L$. cardui from France might be an undescribed species (see Acknowledgements). Accordingly, I terminated our testing of the weevils from Greece, in order to concentrate on testing the Lixus from France, whose host range might be more restricted.

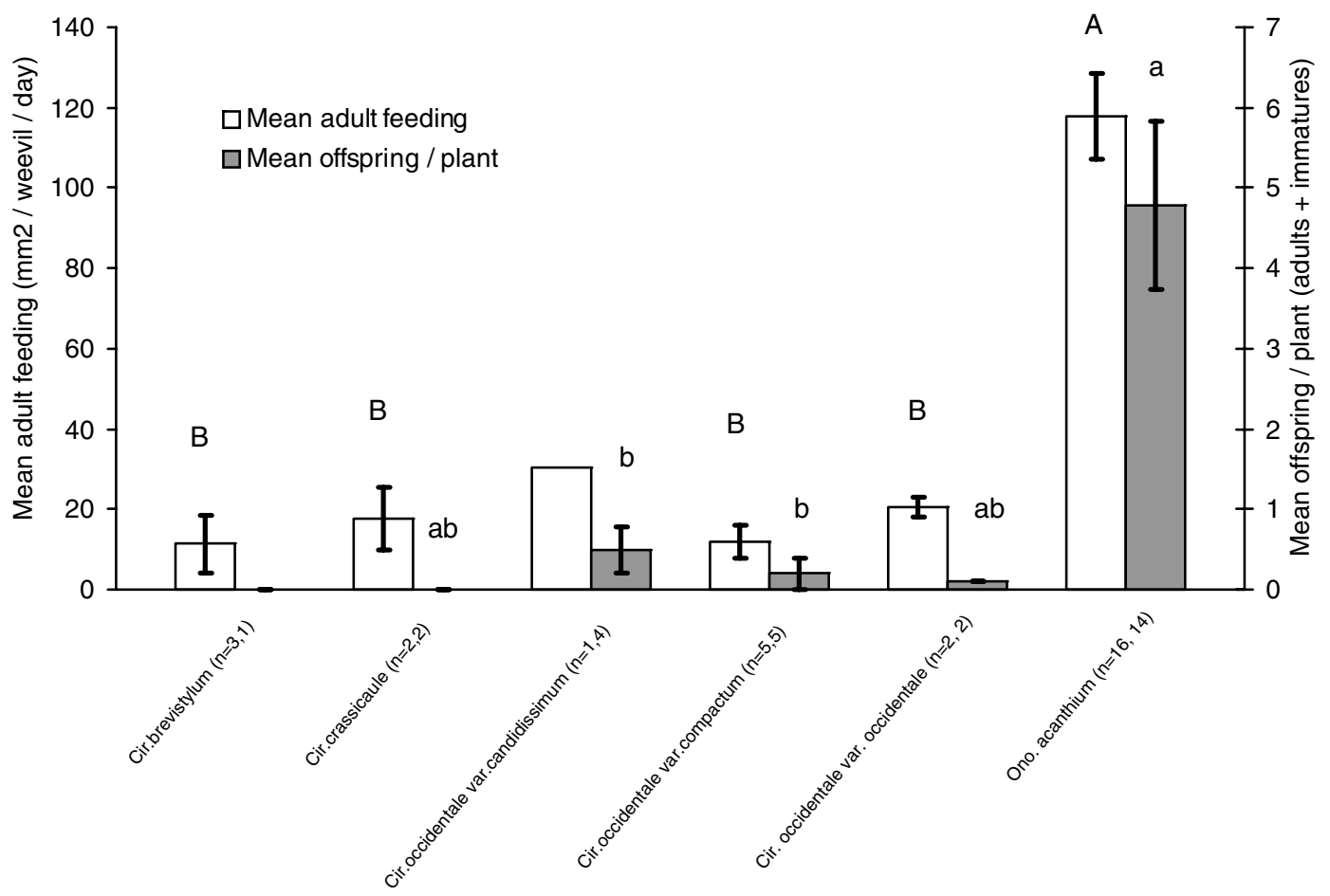

Fig. 3. Mean amount of adult feeding $\left(\mathrm{mm}^{2}\right)$ and mean number of immatures and adults subsequently developing on each test plant species exposed to Lixus cardui from northern Greece under choice conditions. The two $n$-values after each plant species name indicate the number of replicates with feeding scores and developmental data, respectively. If the letters above the species bar are identical, then the means are not significantly different $(P \leqslant 0.05$, Tukey's HSD Test). 
With the 230 weevils I had collected near Montpellier, France, we were able to set up eight no-choice tests, and nearly a dozen choice tests. Under no-choice conditions, the Lixus from France fed and oviposited on both varieties of Cirsium occidentale that we tested, at rates statistically similar to the mean 4.0 larvae and adults that developed on the Scotch thistle controls (Fig. 4). In one of the tests with Cirsium occidentale var. compactum, the weevils failed to develop from either the Scotch thistle control or the test plant. The development data [but not the feeding data] from this test have been excluded from the statistical analyses. The mean feeding damage per weevil per day of $124 \mathrm{~mm}^{2}$ on snowy thistle was statistically greater than the $21 \mathrm{~mm}^{2}$ we observed on artichoke, Cynara scolymus L., but not significantly greater [most likely because of the low number of replicates] than the $79 \mathrm{~mm}^{2}$ on the Scotch thistle controls. In their no-choice tests, the Australians observed feeding by $L$. cardui on artichoke at rates of $10 \%$ of the Onopordum controls (Briese et al., 2004), compared to our $27 \%$. Like the Australians, we did not detect oviposition on artichoke in either of the two no-choice tests of this crop plant, which was statistically less than the mean of 4.0 progeny that developed on each Scotch thistle plant.

A month later, we received a shipment if nearly 10 dozen Lixus from France, and this allowed us to replace the many that had died, and to complete some ongoing and additional choice tests. Even under choice conditions, feeding by the French Lixus was heavy on all three varieties of Cirsium occidentale (Fig. 5). There was significantly less feeding and no oviposition on musk thistle, Carduus nutans, Cirsium crassicaule, and artichoke. During our five choice tests on musk thistle, we observed very low feeding $\left(0.03 \mathrm{~mm}^{2}\right.$ per weevil per day), while the Australian researchers, during their no-choice tests, recorded feeding equivalent to $13 \%$ of that on Onopordum spp. (Briese et al., 2004).

\section{Discussion}

Releasing a weevil that damages and develops on native North American thistles would be ill-advised. The European weevil Rhinocyllus conicus Frölich (Coleoptera: Curculionidae), approved for release in the USA in 1969 to control musk thistle, Carduus nutans, and later, to control other related thistles, has now become notorious because of the damage it causes to native thistles (Turner et al., 1987; Louda et al., 1997; Louda, 2000). USDA-APHIS has withdrawn permits to transport $R$. conicus across state lines (Piper and Coombs, 2004) and it is no longer considered acceptable to use it as a biological control agent (Balciunas and Coombs, 2004). Another weevil, Larinus planus (Fabricius) (Coleoptera: Curculionidae) damages the native Tracy's thistle, Cirsium undulatum var. tracyi (Rydberg) (Louda and O'Brien, 2002). Although it is not an 'approved' agent, the accidentally-introduced $L$. planus is sometimes sold as a biological control agent for Canada thistle, Cirsium arvense (L.) Scopoli, and even distributed by government agencies. The use of unapproved natural

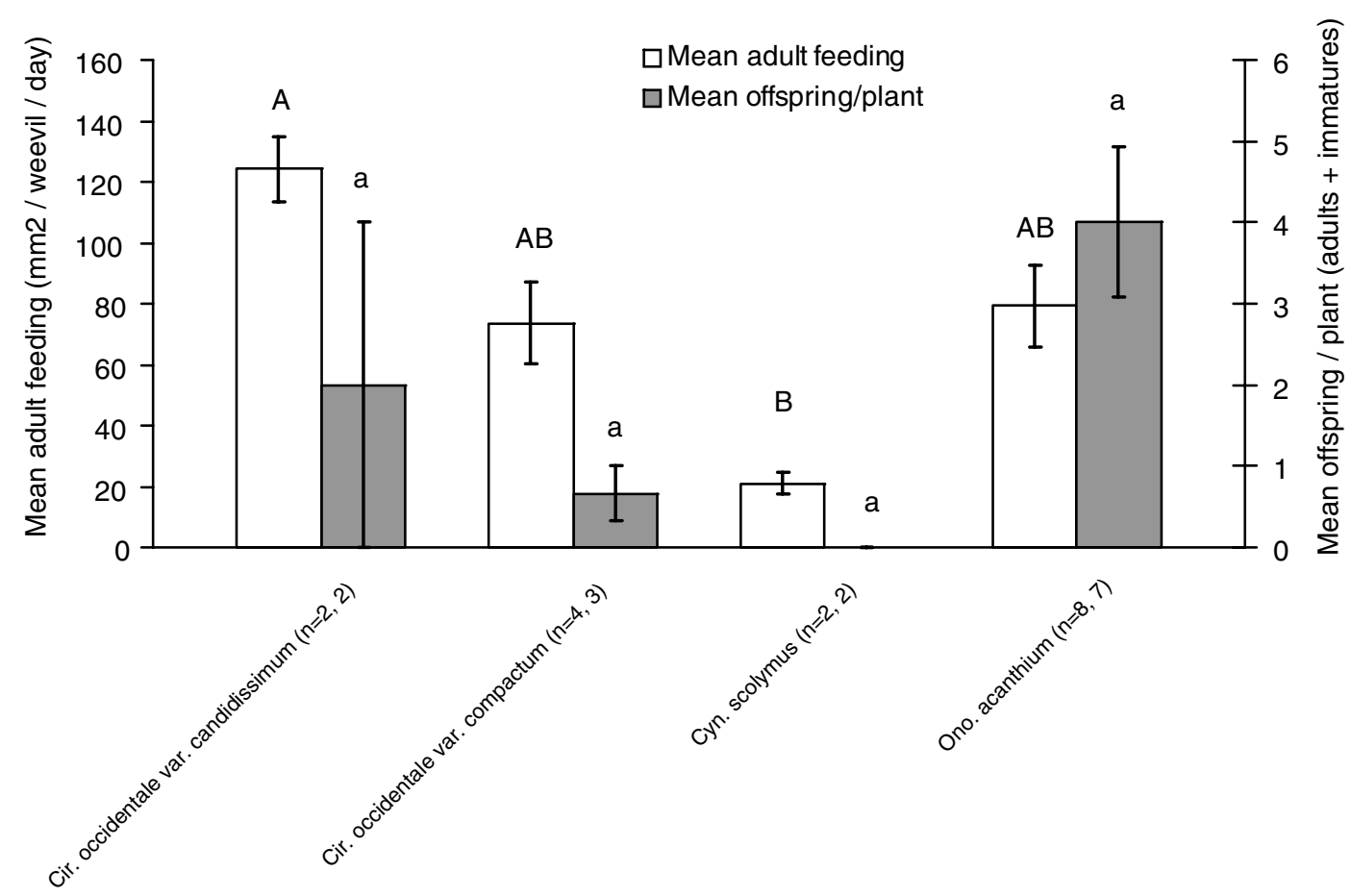

Fig. 4. Mean amount of adult feeding $\left(\mathrm{mm}^{2}\right)$ and mean number of immatures and adults subsequently developing on each test plant species exposed to Lixus cardui weevils from southern France under no-choice conditions. The two $n$-values after each plant species name indicate the number of replicates with feeding scores and developmental data, respectively. If the letters above the species bar are identical, then the means are not significantly different $(P \leqslant 0.05$, Tukey's HSD Test). 


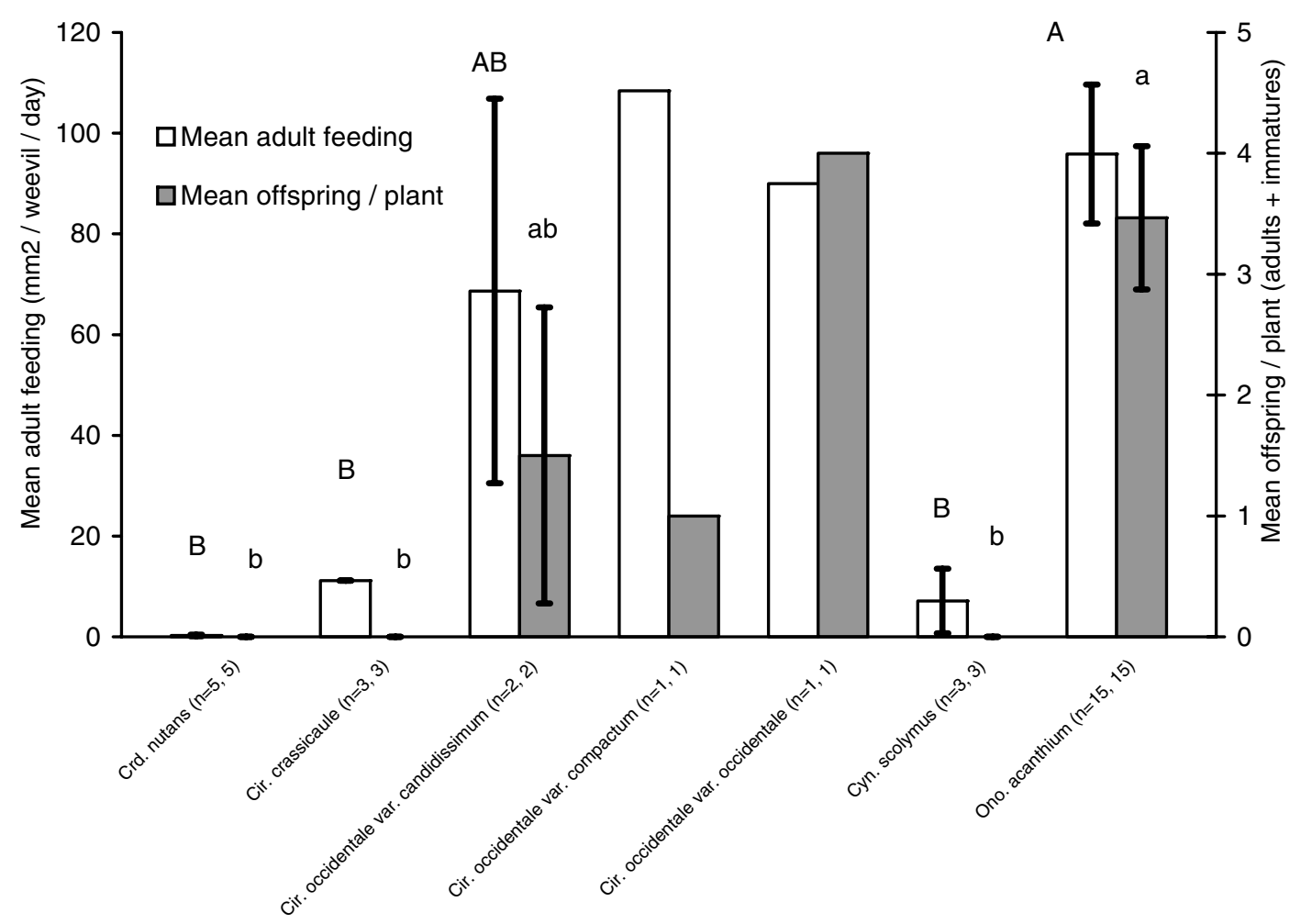

Fig. 5. Mean amount of adult feeding $\left(\mathrm{mm}^{2}\right)$ and mean number of immatures and adults subsequently developing on each test plant species exposed to Lixus cardui from southern Greece under choice conditions. The two $n$-values after each plant species name indicate the number of replicates with feeding scores and developmental data, respectively. If the letters above the species bar are identical, then the means are not significantly different $(P \leqslant 0.05$, Tukey's HSD Test).

enemies for biological control is misguided, and violates one of the 12 Guidelines of the "International Code of Best Practices for Classical Biological Control of Weeds" (Balciunas, 2000; Balciunas and Coombs, 2004).

It would have been desirable to do more tests with both the French and Greek populations of $L$. cardui to get more replicates, thus allowing stronger statistical inferences. However, completing more tests would have required at least one more year and several more shipments of Lixus weevils. But it appeared highly likely that if Lixus weevils, whether from France or Greece, were released in western USA, they would probably feed heavily and develop on some of our native thistles. They might even damage artichoke crops, although they probably would not complete development on them. Devoting scarce plants, valuable quarantine space, and donors' funds on further testing of Lixus weevils that would likely never be released did not seem prudent or ethical. I, therefore, terminated both our Greek and French colonies of Lixus, and began testing another potential biological control agent for this weed, Trichosirocalus briesei Alonso-Zarazaga \& Sanchez-Ruiz (Coleoptera: Curculionidae).

Persons familiar with classical biological control of weeds know that a large portion of potential biocontrol agents never get released. Nonetheless, we are sometimes accused of "... releasing agents willy-nilly" (Strong, 1997, p. 1059). The research I report here, and my decision to not seek the release of this potentially effective weed biocontrol agent for a severe, noxious weed because it might damage native thistles, should help to refute this type of allegation.

The research reported here illustrates both the benefits and drawbacks of a 'transfer' biological control of weeds project. Drawing on the experiences of Australian researchers, I was able to avoid the typical high costs of conducting overseas surveys and field testing. Although some overseas effort was required-I did go overseas and collect most of the Lixus weevils used in our tests - the cost was minor, compared to starting a new project overseas. Ultimately, although L. cardui was safe to use in Australia where there are few natives closely related to Scotch thistle, I felt that it was inappropriate to release in United States, where there are many native thistle species, some of which are as susceptible to attack by $L$. cardui as the target, Scotch thistle. A transfer project might provide a shortcut, but it is not a panacea, and like any biological control project, due caution must be exercised.

\section{Acknowledgments}

The financial support provided by Oregon Department of Agriculture's Noxious Weed Program, and the in-kind assistance from California Department of Food and Agriculture's biological Control Program, helped launch this 
research. Mr. J. Kashefi assisted with collecting the weevils in Greece, while R. Sobhian assisted with the collections in France. Alonso-Zarazaga alerted me to the possibility that the Lixus from France might represent an undescribed species. I thank Kathy Chan for raising the test plants and assisting in conducting the host range tests, and Chris Mehelis for assisting with the data analyses and preparation of figures. I appreciate the helpful comments on earlier drafts of this manuscript by D. Briese, E. Coombs, J. Cuda, L. Kok, M. Pitcairn, and Lincoln Smith.

\section{References}

Balciunas, J.K., 2000. Code of best practices for classical biological control of weeds. In: Spencer, N.R. (Ed.), Proceedings of the 10th International Symposium on Biological Control of Weeds. Montana State University, Bozeman, p. 435.

Balciunas, J.K., Coombs, E.M., 2004. International code of best practices for biological control of weeds. In: Coombs, E.M. Clark, J.K. Piper, G.L., Cofrancesco, A.F., Jr. (Eds.), Biological Control of Invasive Plants in the United States. Oregon State University Press, Corvallis, pp. 130-136.

Bremer, K., 1994. Asteraceae: Cladistics and Classification. Timber Press, Portland, Oregon.

Briese, D.T., 1996. Potential impact of the stem-boring weevil Lixus cardui on the growth and reproductive capacity of Onopordum thistles. Biocontrol Sci. Technol. 6, 251-261.

Briese, D.T., Sheppard, A.W., Zwölfer, H., Boldt, P.E., 1994. Structure of the phytophagous insect fauna of Onopordum thistles in the northern Mediterranean basin. Biol. J. Linn. Soc. 53, 231-253.

Briese, D.T., Sheppard, A.W., Reifenberg, J.M., 1995. Open-field hostspecificity testing for potential biological control agents of Onopordum thistles. Biol. Control 5, 158-166.

Briese, D.T., Pettit, W.J., Swirepik, A., Walker, A., 2002a. A strategy for the biological control of Onopordum spp. thistles in South-eastern Australia. Biocontrol Sci. Technol. 12, 121-136.

Briese, D.T., Walker, A., Pettit, W., Sagliocco, J.-L., 2002b. Hostspecificity of candidate agents for the biological control of Onopordum spp. thistles in Australia: an assessment of testing procedures. Biocontrol Sci. Technol. 12, 149-163.

Briese, D.T., Pettit, W.J., Walker, A., 2004. Evaluation of the biological control agent, Lixus cardui, on Onopordum thistles: experimental studies on agent demography and impact. Biol. Control 31, 165-171.

CAB International, 2004. Crop Protection Compendium, 2004 edition. CAB International, Wallingford, UK. Available from: http://www.cabi.org/compendia/cpc/.

CDFA (California Dept. of Food and Agriculture), 2006. List of pest rating of noxious weed species and noxious weed seed. Available from: http://www.cdfa.ca.gov/phpps/ipc/weedinfo/winfo_list-pestrating. htm.

CNPS (California Native Plant Society), 2001. Inventory of Rare and Endangered Plants of California (sixth edition). California Native Plant Society, Sacramento, CA.

Coombs, E.M., Turner, C.E., 1995. Scotch thistle. In: Rees, N.E., Quimby Jr., P.C., Piper, G.L., Coombs, E.M., Turner, C.E., Spencer, N.R., Knutson, L.V. (Eds.), Biological Control of Weeds in the West. Western Society of Weed Science, Bozeman, MT, unnumbered pages.

Cullen, J.M., 1990. Current problems in host-specificity screening. In: Delfosse, E.S. (Ed.), Proc, VII Int. Symp. Biol. Contr. Weeds, Rome, Italy. Ist. Sper. Patol. Veg. (MAF), pp. 27-36.
Goeden, R.D., 1983. Critique and revision of Harris' scoring system for selection of insect agents in biological control of weeds. Prot. Ecol. 5, 287-301.

Harris, P., 1973. The selection of effective agents for the biological control of weeds. Can. Entomol. 105, 1495-1503.

Hickman, J.C., 1993. The Jepson Manual: Higher Plants of California. University of California Press, Berkeley, CA.

Hooper, J.F., Young, J.A., Evans, R.A., 1970. Economic evaluation of Scotch thistle suppression. Weed Sci. 18, 583-586.

Julien, M.H., Griffiths, M.W., 1998. Biological Control of Weeds: A World Catalogue of Agents and their Target Weeds. CAB International, New York, NY.

Louda, S.M., 2000. Negative ecological effects of the musk thistle biological control agent, Rhinocyllus conicus. In: Follet, P.A., Duan, J.J. (Eds.), Nontarget Effects of Biological Control. Kluwer Academic Publishers, Boston, MA, pp. 215-243.

Louda, S.M., Kendall, D., Kendall, J., Simberloff, D., 1997. Ecological effects of an insect introduced for the biological control of weeds. Science 277, 1088-1090.

Louda, S.M., O’Brien, C.W., 2002. Unexpected ecological effects of distributing the exotic weevil, Larinus planus (F.), for the biological control of Canada thistle. Conserv. Biol. 16, 717-727.

Moore, R.J., Frankton, C., 1974. The Thistles of Canada. Canada Dept. of Agriculture, Ottawa.

Munz, P.A., 1959. A California Flora. University of California Press, Berkeley.

Piper, G.L., Coombs, E.M., 2004. Rhinocyllus conicus. In: Coombs, E.M., Clark, J.K., Piper, G.L., Cofrancesco, A.F., Jr. (Eds.), Biological Control of Invasive Plants in the United States. Oregon State University Press, Corvallis, OR, pp. 365-368.

Rice, P.M., 2006. INVADERS Database System. Division of Biological Sciences, University of Montana, Missoula, MT. Available from: http://invader.dbs.umt.edu.

Sokal, R.R., Rohlf, F.J., 1981. Biometry: the principles and practice of statistics in biological research. W.H. Freeman and Company, New York, N.Y.

Statistix (Version 8.1) [Computer software], 2005. Tallahassee, FL: Analytical software.

Strong, D.R., 1997. Fear no weevil? Science 277, 1058-1059.

Swirepik, A., Smyth, M., 2002. Biological control of broad-leafed pasture weeds (Paterson's curse, Onopordum and nodding thistles): what have we achieved and where to from here?. In: Spafford J.H., Dodd, J., Moore, J.H. (Eds.), Proceedings of the $13^{\text {th }}$ Australian Weeds Conference, Plant Protection of WA, Perth, pp. 373-376.

Turner, C.E., Pemberton, R.W., Rosenthal, S.S., 1987. Host utilization of native Cirsium thistles (Asteraceae) by the introduced weevil Rhinocyllus conicus (Coleoptera: Curculionidae) in California. Environ. Entomol. 18, 111-115.

USDA, NRCS, 2006. The PLANTS Database. National Plant Data Center, Baton Rouge, LA. Available from: http://plants.usda.gov.

Volonik, S.V., 1994. On the oviposition of the genus Lixus (Coleoptera: Curculionidae). Entomol. Rev. 74, 115-120.

Whitson, T.D., Burrill, L.C., Dewey, S.A., Cudney, D.W., Nelson, B.E., Lee, R.D., Parker, R., 1996. Weeds of the West, Fifth ed. Western Society of Weed Science, Jackson, Wyoming.

WSSA (Weed Science Society of America), 1989. Composite list of weeds. Report of the standardized plant names subcommittee. Weed Science Society of America, Champaign, IL.

Young, J.A., Evans, R.A., 1969. Control and ecological studies of Scotch thistle. Weed Sci. 17, 60-63.

Zwölfer, H., Brandl, R., 1989. Niches and size relationships in Coleoptera associated with Cardueae host plants: adaptations to resource gradients. Oecologia 78, 60-68. 